\title{
Determinants of Contraceptive Practice Among Married Women, in the Health District of Dahra, Senegal
}

\author{
Ndiaye papa ${ }^{1 *}$, Mbaye mamadou thioro², Niang Khadim ${ }^{3}$ and Gning maurice ${ }^{4}$ \\ ${ }^{1}$ Public Health Department, Gaston Berger University (UGB) of Saint-Louis, Senegal \\ ${ }^{2}$ Gynecologist and Public Health physician, Health District of Dahra, Senegal \\ ${ }^{3}$ Public Health Department, Cheikh Anta Diop University (UCAD) of Dakar, Senegal \\ ${ }^{4}$ English Department, Gaston Berger University (UGB) of Saint-Louis, Senegal
}

Submission: June 01, 2018; Published: June 26, 2018

"Corresponding author: Papa Ndiaye, Public Health Department, Gaston Berger University (UGB) of Saint-Louis, Senegal,

Email: pndiayempsp@gmail.com

Keywords: Mother Child Health Support Project; PASME; District of Dahra; knew family planning; Injectable methods; income-generating activity

\section{Introduction}

In Senegal, the contraceptive prevalence rate among married women was estimated in 2015 at $22 \%$ at the national level [1]. It was particularly weak in the health district of Dahra (14\%). The health district has, since, benefited from the support of the United Nations Population Fund (UNFPA) and the Mother and Child Health Support Project / Projet d'Appui à la Santé de la Mère et de l'Enfant (PASME). PASME is funded by the French Development Agency / Agence Française de Développement (AFD). Thus, several interventions focused on communication and strengthening health care were made. At the end of the first year, the objective of this study was to re-evaluate the contraceptive prevalence and its main determinants in order to propose recommendations.

\section{Method}

A cross-sectional, descriptive and analytical study was conducted from 8 to 22 June 2016 in the health district of Dahra $\left(6,980 \mathrm{~km}^{2}\right.$ for 151,446 inhabitants). It was centered on women of childbearing age (15-49 years), married, and residing in the health district for, at least, 6 months. These women were selected according to a two-stage cluster survey (village then concession). The sample, calculated with the Schwartz formula and taking into account the cluster effect, was $\mathrm{n}=([1,962 * \mathrm{*} \mathrm{p} * \mathrm{q}] / \mathrm{I} 2)$ 米 $2=$ 185 米 $2=370$. It was adjusted to 450 in order to have 30 clusters of 15 women to investigate. Data, collected in households using a questionnaire in individual interviews, were entered and analyzed with Epi Info software 3.5.3.
Result

The number of respondents was 433 (96\%). The age, variable from 15 to 49 years, had an average of $29( \pm 7.8)$. The majority of women were from rural area $(69,3 \%)$ and in monogamous marital regime (62.3\%). Among them, 89\% knew family planning (FP); and $66.1 \%$ of husbands approved FP. The contraceptive prevalence reached $28.4 \%$ and the injectable methods were the most used (44.7\%). The proportion of women with unmet need for FP was $20.3 \%$. Contraceptive practice was greater among those who: resided in urban area, had an income-generating activity, and/or had a husband who approves FP.

Table 1: Description of the Population of the Population.

\begin{tabular}{|c|c|c|c|}
\hline \multirow{2}{*}{$\begin{array}{l}\text { Description of } \\
\text { the Population }\end{array}$} & \multicolumn{3}{|c|}{ Modalities } \\
\hline & Yes & No & Total \\
\hline Age $<25$ years & $139(32,10 \%)$ & $294(67,90 \%)$ & 433 \\
\hline Children alive $>3$ & $190(43,88 \%)$ & $243(56,12 \%)$ & 433 \\
\hline Last child $\leq 2$ ans & $247(57,04 \%)$ & $186(42,96 \%)$ & 433 \\
\hline Urban residence & $133(30,72 \%)$ & $300(69,28 \%)$ & 433 \\
\hline Instruction & $336(77,60 \%)$ & $97(22,40 \%)$ & 433 \\
\hline $\begin{array}{c}\text { RGA (revenue } \\
\text { generated activity) } \\
/ \text { English }\end{array}$ & $240(55,43 \%)$ & $193(44,57 \%)$ & 433 \\
\hline Monthly income & $296(68,36 \%)$ & $137(31,64 \%)$ & 433 \\
\hline $\begin{array}{c}\text { Husband } \\
\text { favourable to FP }\end{array}$ & $228(66,09 \%)$ & $117(33,91 \%)$ & 345 \\
\hline
\end{tabular}


Table 2: Looking for Determinants of Family Planning (Fp) Practice.

\begin{tabular}{|c|c|c|c|c|c|}
\hline \multicolumn{2}{|c|}{$\begin{array}{l}\text { Looking for Determinants of Family } \\
\text { Planning (Fp) Practice }\end{array}$} & \multicolumn{2}{|c|}{ FP } & \multirow[t]{2}{*}{ p- value } & \multirow[t]{2}{*}{ OR } \\
\hline & & Yes & No & & \\
\hline \multirow{2}{*}{ Age } & Ado/Youths & 33 & 106 & \multirow{2}{*}{0,138} & \multirow{2}{*}{---} \\
\hline & Adults & 90 & 204 & & \\
\hline \multirow{2}{*}{$\begin{array}{l}\text { Number of living } \\
\text { children }\end{array}$} & $>3$ & 62 & 128 & \multirow{2}{*}{0,08} & \multirow{2}{*}{---} \\
\hline & $\leq 3$ & 61 & 182 & & \\
\hline \multirow{2}{*}{ Last children age } & $\leq 2$ years & 80 & 167 & \multirow{2}{*}{0,034} & \multirow{2}{*}{$1,59[1.03-2.45]$} \\
\hline & $>2$ years & 43 & 143 & & \\
\hline \multirow{2}{*}{ Residence } & Urbane & 49 & 84 & \multirow{2}{*}{0,009} & \multirow{2}{*}{1,78 [1.14-2.76] } \\
\hline & Rural & 74 & 226 & & \\
\hline \multirow{2}{*}{ Instruction } & Yes & 98 & 238 & \multirow{2}{*}{0,54} & \multirow{2}{*}{---} \\
\hline & No & 25 & 71 & & \\
\hline \multirow{2}{*}{$\begin{array}{l}\text { Revenue generated } \\
\text { activity }\end{array}$} & Yes & 78 & 162 & \multirow{2}{*}{0,035} & \multirow{2}{*}{$1.58[1.03-2.43]$} \\
\hline & No & 45 & 148 & & \\
\hline \multirow{2}{*}{ Monthly income } & $>50000$ & 45 & 130 & \multirow{2}{*}{0,3} & \multirow{2}{*}{---} \\
\hline & $\leq 50000$ & 78 & 180 & & \\
\hline \multirow{2}{*}{$\begin{array}{c}\text { Social organisation } \\
\text { member }\end{array}$} & Yes & 89 & 207 & \multirow{2}{*}{0,25} & \multirow{2}{*}{---} \\
\hline & No & 34 & 103 & & \\
\hline \multirow{2}{*}{ Husband's position } & For & 100 & 128 & \multirow{2}{*}{$<0,001$} & \multirow{2}{*}{$4,60[2,50-8,10]$} \\
\hline & Against & 17 & 100 & & \\
\hline
\end{tabular}

\section{Discussion}

The limits of this study are of three kinds [2,3]: Unmarried women who represent $35 \%$ of the women of childbearing have been overshadowed. The characteristics of women with unmet need for FP were not studied. The peculiarities of the service offer were not detailed.The estimated prevalence $(28.4 \%)$ is above the national average of $22 \%$. Four main factors influenced contraceptive practice: husband's attitude, place of residence, economic occupation and age of the last child. These data are comparable to the Faye M series in Ngaye Mékhé District, which found a contraceptive prevalence of $28.6 \%$ in 2015 [4].The unmet need for family planning (20.3\%) was similar to that of the 2014 demographic and health survey (DHS), which found that $25.6 \%$ of women had a SNB in FP, of which $19.2 \%$ for spacing and $6.3 \%$ for limiting births [1].

\section{Conclusion}

At the health district of Dahra, the contraceptive prevalence rate has been raised but remains low. Its improvement requires a real global and inclusive dynamics for all actors. This calls for a multi-sectorial and interdisciplinary approach, aimed at empowering women and involving husbands, especially in rural areas.

\section{References}

1. Senegal (2015) Agence Nationale de la Statistique et de la Démographie (ANSD). Enquête Démographique et de santé Continue 2014. Rockville, Maryland, USA.

2. WHO (2014) Mortalité planification familiale/contraception aidemémoire, p. 348.

3. Senegal (2016) Ministère de la santé et de l'action sociale, Direction de la santé de la reproduction et de la survie de l'enfant. Cadre stratégique national de planification familiale 2016-2020. P. 62.

4. Faye M (2015) Etude des déterminants de la faible utilisation de la contraception dans le district de Mékhé au Sénégal en. 
CC (i) This work is licensed under Creative Commons Attribution 4.0 License DOI: 10.19080/JGWH.2018.10.555784

\section{Your next submission with Juniper Publishers} will reach you the below assets

- Quality Editorial service

- Swift Peer Review

- Reprints availability

- E-prints Service

- Manuscript Podcast for convenient understanding

- Global attainment for your research

- Manuscript accessibility in different formats

( Pdf, E-pub, Full Text, Audio)

- Unceasing customer service

Track the below URL for one-step submission https://juniperpublishers.com/online-submission.php 